\section{References}

1. Jonas RA, Quaegebeur JM, Kirklin JW, Blackstone EH, Daicoff G. Outcomes in patients with interrupted aortic arch and ventricular septal defect. A multiinstitutional study. Congenital Heart Surgeons Society. J Thorac Cardiovasc Surg. 1994;107:1099-13.

2. Daubeney PEF, Blackstone EH, Weintraub RG, Slavik Z, Scanlon J, Webber SA. Relationship of the dimension of cardiac structures to body size: an echocardiographic study in normal infants and children. Cardiol Young. 1999;9:402-10.

3. Bove EL, Minich LL, Pridjian AK, Lupinetti FM, Snider AR, Dick M 2nd, et al. The management of severe subaortic stenosis, ventricular septal defect, and aortic arch obstruction in the neonate. $J$ Thorac Cardiovasc Surg. 1993;105:289-96.

4. Gava T, Hornberger LK, Sanders SP, Jonas RA, Ott DA, Colan SD. Echocardiographic predictors of left ventricular outflow tract obstruction after repair of interrupted aortic arch. J Am Coll Cardiol. 1993; 22:1953-60.

5. Schreiber C, Eicken A, Vogt M, Gunther T, Wottke M, Thielmann M, et al. Repair of interrupted aortic arch: results after more than 20 years. Ann Thorac Surg. 2000;70:1896-900.

6. Serraf A, Lacour-Gayet F, Robotin M, Bruniaux J, Sousa-Uva M, Roussin R, et al. Repair of interrupted aortic arch: a ten-year experience. J Thorac Cardiovasc Surg. 1996;112:1150-60.

7. Apfel HD, Levenbraun J, Quaegebeur JM, Allan LD. Usefulness of preoperative echocardiography in predicting left ventricular outflow obstruction after primary repair of interrupted aortic arch with ventricular septal defect. Am J Cardiol. 1998;82:470-3.

8. Salem MM, Starnes VA, Wells WJ, Acherman RJ, Chang RK, Luciani GB, et al. Predictors of left ventricular outflow obstruction following single-stage repair of interrupted aortic arch and ventricular septal defect. Am J Cardiol. 2000;86:1044-7, A11.

9. Luciani GB, Ackerman RJ, Chang AC, Wells WJ, Starnes VA. Onestage repair of interrupted aortic arch, ventricular septal defect, and subaortic obstruction in the neonate: a novel approach. $J$ Thorac Cardiovasc Surg. 1996;111:348-58

10. Goldmintz E, Baffa JM, Weinberg PM. Evaluation of the subaortic region in interrupted aortic arch. J Am Coll Cardiol. 1992;19:233A.

\title{
ON THE MOVE? \\ Send us your new address at least six weeks ahead
}

Don't miss a single issue of the journal! To ensure prompt service when you change your address, please photocopy and complete the form below.

Please send your change of address notification at least six weeks before your move to ensure continued service. We regret we cannot guarantee replacement of issues missed due to late notification.

\section{JOURNAL TITLE:}

Fill in the title of the journal here.

OLD ADDRESS:

Affix the address label from a recent issue of the journal here.

\section{NEW ADDRESS:}

Clearly print your new address here.

Name

Address

City/State/ZIP

\section{COPY AND MAIL THIS FORM TO:}

Elsevier Inc.

Subscription Customer Service

6277 Sea Harbor Dr

Orlando, FL 32887
OR FAX TO:

407-363-9661

OR E-mail:

elspcs@elsevier.com
OR PHONE:

800-654-2452

Outside the U.S., call

407-345-4000 